\title{
Towards Enhanced Tax Compliance in Kenya
}

\author{
SAN LIO \\ Chandaria School of Business, United States International University-Africa \\ JOHN MIRICHII \\ Chandaria School of Business, United States International University-Africa
}

Received: Sep. 29, 2017 Accepted: May 30, $2018 \quad$ Published: June 1, 2018

doi:10.5296/ajfa.v10i1.11930 URL: https://doi.org/10.5296/ajfa.v10i1.11930

\begin{abstract}
Tax is the bottom line source of revenue for the world's governments. Taxation is the only known realistic means of collecting resources to finance public expenditure. This study aims at unraveling efficient mechanisms to be employed in Kenya to enhance income tax compliance to boost tax revenue for the current and future governments. With the new governance structure of forty seven county governments in place following the promulgation of the new constitution 2010, this exercise is timely. This was a descriptive survey study and used both secondary and primary sources of data in eliciting the required information necessary for the research findings. The sample size was made up of two hundred thirty seven companies drawn from the Kenyan manufacturing sector firms operating within the Nairobi County.

The Statistical Package for the Social Sciences (SPSS) version 20was used in the data analysis and presentation of findings. The overall finding was that a tax system should be simple, withstraightforward rules for lay citizens to understand and at the same time guarantee that the cost of tax collection and administration is not higher than the actual tax revenue raised.

The research findings lead to a conclusion that multiple rates of income tax, varied dates of making tax returns and a bulky legal tax framework make income tax compliance unforeseeable in Kenya.
\end{abstract}

Keywords: Kenya Revenue Authority, Taxable income, Tax rates, Tax regimes, Legal tax framework 


\section{Introduction}

The purpose of taxation in Kenya is to finance government planned activities. Article 209 of the Constitution of Kenya 2010 grants powers to impose taxes as a revenue source by both the national and the county governments. Tax may be defined as a levy charged by governments either on individuals' or corporate entities' incomes and/or on the price of a good or service. The former is known as direct tax and the latter indirect tax. The focus of the study is income tax, in the category of the direct tax, which accounts for approximately forty percent $(40 \%)$ of the total tax revenue in Kenya.

The G20 summit in Moscow held in September 2013 had observations on tax evasion in Africa worth noting. Available data indicate that the amounts of tax revenue lost by the African nations between 1970 and 2010 amounted to eight hundred fourteen billion USA dollars. This amount is twice, the level of development aid given to the continent the same period. The loss is today estimated at thirty eight billion USA dollars a year, according to experts (Business Daily, 2013). The loss is mainly corporation tax, and is not only attributable to individuals and Small and Medium Enterprises (SMEs), but also renowned Multinational Corporations. Since factually every coin earned in Kenya is subject to income tax, and with the tax rate averaging approximately thirty percent, the loss in income tax revenue in Kenya could be estimated at Kenya Shillings seven hundred billion a year.

This raises important questions on tax evasion, avoidance and planning, as well as compliance in Kenya and Africa.

Kenya's GDP for the year 2013 was estimated at $\$ 40.7$ billion, with economic growth of $4.6 \%$ in the year 2012 compared to $4.4 \%$ in the year 2011. This growth was envisaged to be $5.7 \%$ in 2013 and $6.0 \%$ in 2014 (World Bank, 2013), with income tax revenue averaging $10 \%$ of GDP.

The country however has the potential to achieve a double digit GDP growth rate as the economic performance over the past decade has lagged behind the average for sub-Saharan Africa. Accordingly, the country's income tax potential is untapped.

Income tax is a direct tax charged on incomes of individuals and corporate entities, from employment, self-employment, profits on trading activities, rent, dividends, interests, pensions, royalties, professional fees, and other incomes. These sources of income on individuals may not all be accounted for via the PAYE system, with different rates applied, making the process of accountability and compliance difficult. Kenyan resident and non-resident corporate entities are charged different tax rates. The tax is also dependent on whether the company is listed in the Nairobi Stock Exchange (NSE), percentage of issued share capital, number of years as a listed company, gross income, and whether the company is in the Export Processing Zone (EPZ).

Tax is also charged on the income earned by persons resident in Kenya. A resident is defined for tax purposes as an individual who has permanent residence in Kenya, and has spent any part of the working year(s) in the country; or, one without permanent residence in Kenya but has spent one hundred eighty three days or more, working in the country during the period of 
assessment. A foreign employee in a non-Kenyan firm who is resident in Kenya is subject to income tax on all emoluments. To avoid double taxation on resident individuals and corporate entities earning income by contacting business in other countries, Kenya has signed double taxation treaties with most nations.

Income tax is governed under the Income Tax Act Cap 470, of the Laws of Kenya. The principle law, the Income Tax Act has 14 parts, 133 sections and 13 schedules, all directing its implementation. Besides these, are the finance bills and Acts issued regularly to amend the main Act. This brings to fore, a glaring complexity on the ordinary citizen and professionals alike.

\section{Indirect Taxes}

Indirect taxes may be categorised as including the VAT, excise duty, import duty and stamp duty \& other taxes. VAT is levied on the consumption of goods and services, and charged at each stage of production and distribution chain to the retail stage. The tax is charged on the value added on the good or service. It is also levied on imported taxable goods and services. Traders are allowed to offset input VAT against output VAT in the final accounting, usually done on or before the twentieth day following the trading month. The rates (PwC, 2014) vary, ranging from zero, for the items that are zero rated and twelve percent on petroleum products. The standard rate in Kenya is sixteen percent. VAT is governed under the VAT Act Cap 476, of the Laws of Kenya, which has fifty nine sections, nine schedules and nine subsidiaries.

Excise duty is a tax charged on traders, but passed on to the consumers in form of increased prices. The rates vary accordingly: ordinary beer is charged at Kenya Shillings Seventy a litre or fifty percent of ex factory selling pricing; other alcoholic beverages between Kenya Shillings seventy, eighty or one hundred twenty a litre or thirty five percent of the value (whichever is higher) or fifty percent ex factory selling pricing; tobacco at Kenya Shillings one thousand two hundred per mile or thirty five percent of recommended selling price (RSP), excisable services are charged between seven and fifty percent depending on the service and various other rates for other excisable products. There is no specific chapter of law dealing with this particular tax.

Import duty is charged on imported goods and services, and paid before the items are allowed passage into the country from the ports. The rates are: rice $35 \%$, wheat grain $10 \%$, maize grain $50 \%$, of the selling prices among other rates charged on various imported items. Other than the East African Community Customs Union (EACCU) established in the year 2005 to harmonize importation of goods and services into the partner states, and which provides the rates to be applied accordingly, there is no chapter of the Kenyan laws dealing with this particular tax.

There is currently no export duty/tax charged in Kenya. In fact the Government of Kenya through the Tax Remission for Exports Office encourages local manufacturers to export their products. This is achieved by remitting duty and VAT on raw materials used in the manufacture of goods for export.

Stamp duty tax is charged as follows: transfer of immovable property within a county, $4 \%$; 


\section{Macrothink}

Asian Journal of Finance \& Accounting

ISSN 1946-052X 2018, Vol. 10, No. 1

outside a county, $2 \%$; issue of debentures or mortgage, $0.1 \%$; transfer of unquoted and quoted stock of marketable securities, $1 \%$ and $0 \%$ percent respectively; creation and/or increase of share capital, $1 \%$; lease of a period of zero to three years and more, $1 \%$ and $2 \%$ respectively, among others.

In the case of excise, import and stamp duty taxes, there are in consistencies in as far as the legal frameworks are concerned.

\section{Motivation of the Study}

Tax compliance in Kenya has been at its lows since independence, as witnessed by the low tax revenues. In the financial year 2000/01 for example, revenue collected from taxes amounted to Kenya Shillings 200 billion, rising to only Kenya Shilling 800 billion in the financial year 2011/2013, a period of over ten years. Kenya's GDP has been growing steadily at almost the same rate, rising from sixteen billion USA dollars in the financial year 2003/4 to thirty seven billion dollars in the financial year 2012/13. The tax revenue base should have been expected to grow at a much higher rate than what has been witnessed, to sufficiently fund government planned development projects, with deficits experienced to date; as can be seen in the table 1.

Table 1.

\begin{tabular}{|c|c|c|c|c|}
\hline \multicolumn{4}{|l|}{ Vote } & Year \\
\hline & $2009 / 10$ & $2010 / 11$ & $2011 / 12$ & $2012 / 13$ \\
\hline & Ksh billion & Ksh billion & Ksh billion & Ksh billion \\
\hline Revenue & 574.10 & 673.27 & 781.63 & 971.33 \\
\hline Expenditure & 574.30 & 733.35 & 833.02 & $1,123.42$ \\
\hline Deficit & 0.20 & 60.08 & 51.39 & 152.09 \\
\hline
\end{tabular}

Source: Kenya bureau of statistics, facts \& figures 2013 \& office of the controller of budget 2014(Figures in brackets are actual)

For example, budgetary planned activities for the financial year 2013/14, whose theme was transformation and shared prosperity amounted to Kenya shillings 1.6trillion. KRA planned to collect the amount of Kenya Shillings 974billion, hence an anticipated deficit of Kenya Shillings 626 billion (Kenya National Bureau of Statistics, 2013). These accumulated deficits have continued to raise the debt burden on the Kenyan people, estimated at Kenya Shillings two point one trillion (Ksh 2.11 trillion), which is $58 \%$ of the country's GDP.

The types of tax revenue streams in Kenya, from which the above mentioned revenue is derived, include income tax, VAT, excise duty, import duty, stamp duty and others; accounting for $40 \%, 28 \%, 15 \%, 8 \%$ and $9 \%$ respectively.Accordingly, income tax accounts 
for the lion's share of the Kenya's tax revenue at forty percent hence the focus of this research work. The amounts collected in recent years relative to GDP are summarized in Table 2.

Table 2. Income Tax Revenue Collection

\begin{tabular}{|lllll|}
\hline Item & & & Year & \\
& $2009 / 10$ & $2010 / 11$ & $2011 / 12$ & $2012 / 13$ \\
& Ksh billion & Ksh billion & Ksh billion & Ksh billion \\
\hline $\begin{array}{l}\text { Income } \\
\text { revenue }\end{array}$ & 219 & 272 & 329 & 403 \\
\hline $\begin{array}{l}\text { Government } \\
\text { Expenditure }\end{array}$ & 574 & 733 & 833 & 1,123 \\
\hline $\begin{array}{l}\text { \%Contribution } \\
\text { Expenditure }\end{array}$ & $\mathbf{3 8 \%}$ & $\mathbf{3 7 \%}$ & $\mathbf{3 9 \%}$ & $\mathbf{3 6 \%}$ \\
\hline $\begin{array}{l}\text { GDP } \\
\text { \%ocontribution }\end{array}$ & $\mathbf{9 \%}$ & $\mathbf{2 3 6}$ & $\mathbf{1 1 \%}$ & $\mathbf{1 2 \%}$ \\
\hline \begin{tabular}{l} 
GDP \\
\hline
\end{tabular} & & $\mathbf{1 1 \%}$ & 3049 & \\
\hline
\end{tabular}

Source: Kenya bureau of statistics, facts \& figures 2013

These figures translate to an average of $37 \%$ contribution on government planned expenditure, and $11 \%$ of GDP for the financial periods. This in a nutshell, is dismal. The question the researchers seek to answer is why this poor performance?

The Study Hypotheses

$\mathrm{H}_{1}$ Multiple tax rates charged on individuals and corporate entities on various incomes have a significant relationship with income tax revenue poor performance in Kenya

$\mathrm{H}_{2}$ Disparate dates set by KRA for filling and accounting for income tax returns have a significant relationship with income tax revenue poor performance in Kenya

$\mathrm{H}_{3}$ Bulky legislation and unfriendly legal jargon in the Kenya's income tax Act has a significant relationship with income tax revenue poor performance in Kenya.

\section{Theoretical Review}

Kenya's economy is operating below its potential (World Bank, 2013) hence unable to achieve its tax revenue objectives. However, the triumphant elections held in March 2013 and 
the peaceful handover of power in the following month of April ushered in a new era of political leadership in Kenya, which would guide the implementation of Kenya's ambitious program of devolution. If these developments reflected the maturing of Kenya's political system, there was equal optimism that Kenya had put behind the troubling economic periods that had regularly followed its previous election cycles. Kenya could do much better, and there was no doubt that the new government wanted to unleash the potential of the Kenyan economy. This would see poverty levels reduce from the estimated forty two percent and bring in more individuals into the income tax bracket. However to enhance income tax collections, a simple tax system is envisaged. Many authors have taken interest in the administration of income tax in its current bureaucratic form, and largely ignored the more fundamental issues of simplicity and transparency, expected to enhance revenue.

A simple tax system is one that ordinary tax payers are able to understand (Holtzman, 2007). The IMF (2001) contends that simplicity of a tax system is paramount. The Tax Justice Network for Africa (TJN-A) (2014), notes that the tax system in Kenya is derived from the colonial laws which are heavily complicated. According to the Institute of Economic Affairs Kenya (IEA-K) (2006) Kenya introduced a Tax Modernisation Programme in 1986 with the hope that this would, among other things, improve tax administration and reduce compliance and collection costs without success. IEA-K (2012) has promoted the breakdown of Kenya's complex tax system into a user friendly scheme. Cheeseman and Robert(2004) found that governance issues have been largely to blame for ill tax revenue performance in most sub-Sahara African nations. They add that KRA's focus should have been working on mechanisms to simplify particularly the income tax system since this tax accounts for the biggest percentage of government revenue.

\section{Methodology}

The population of the study consisted of 582 companies drawn from Kenya Association of Manufactures (KAM) in the Nairobi County.Nairobi County was selected because of its size in economic performance, with the second largest County, Kakamega, having a budget half that of Nairobi, and smallest nearly sixteen times less.Table 3 shows the largest four, and smallest Counties in Kenya budget wise, and revenue sources. A sample of 237 financial managers was selected using the Yamane formula. 
Table 3.

\begin{tabular}{|l|l|l|l|l|}
\hline \multirow{2}{*}{ County } & \multirow{2}{*}{$\begin{array}{l}\text { Kudget } \\
\text { Ksh billion }\end{array}$} & \multicolumn{2}{|c|}{ Revenue Source } \\
\cline { 3 - 6 } & & $\begin{array}{l}\text { National } \\
\text { government } \\
\text { Ksh billion }\end{array}$ & \multicolumn{2}{|l|}{ Sources } \\
\cline { 3 - 6 } & & & $\begin{array}{l}\text { Ksh } \\
\text { billion }\end{array}$ & \% of total budget \\
\hline Nairobi & 25.3 & 9.4 & 15.9 & $63 \%$ \\
\hline Kakamega & 13.2 & 9.7 & 3.5 & $27 \%$ \\
\hline Mombasa & 11.7 & 6.6 & 5.1 & $44 \%$ \\
\hline Nakuru & 10.0 & 6.9 & 3.1 & $31 \%$ \\
\hline Lamu & 1.6 & 1.514 & 0.086 & $5 \%$ \\
\hline
\end{tabular}

Source: Controller of budget, County reports 2013-2014

A total 237 questionnaires were administered to the respondents and 30 returned for analysis. All the 30 returned questionnaires were complete and met the study requirements. This represented a $13 \%$ response rate. The data was analysed using descriptive statistics specifically frequencies and charts; using the Statistical Package for the Social Sciences (SPSS) version 20.

\section{Results and findings}

The results and study findings on the various variables are summarized in the table 4 and figure 1 
Table 4. Results and Findings

\begin{tabular}{|c|c|c|c|c|}
\hline \multicolumn{3}{|l|}{ VARIABLE } & Understood & Not understood \\
\hline \multirow{2}{*}{$\begin{array}{l}\text { Income tax flat } \\
\text { rates }\end{array}$} & \multicolumn{2}{|l|}{ PAYE } & $88 \%$ & $12 \%$ \\
\hline & \multicolumn{2}{|c|}{ Corporation } & $76 \%$ & $24 \%$ \\
\hline \multirow[t]{5}{*}{ Tax Incentives } & \multicolumn{2}{|c|}{ Tax holidays } & $0 \%$ & $100 \%$ \\
\hline & \multicolumn{2}{|c|}{ Capital allowances } & $47 \%$ & $53 \%$ \\
\hline & \multirow[t]{3}{*}{ Reliefs } & Pensions & $14 \%$ & $86 \%$ \\
\hline & & Insurance & $17 \%$ & $86 \%$ \\
\hline & & Mortgage & $17 \%$ & $86 \%$ \\
\hline \multirow[t]{6}{*}{ Legal framework } & \multirow{2}{*}{$\begin{array}{l}\text { Filing } \\
\text { returns }\end{array}$} & PAYE & $100 \%$ & $0 \%$ \\
\hline & & Corporation & $94 \%$ & $6 \%$ \\
\hline & \multicolumn{2}{|c|}{ Tax Act and Bills } & $0 \%$ & $100 \%$ \\
\hline & \multicolumn{2}{|c|}{ Penalties } & $29 \%$ & $71 \%$ \\
\hline & \multicolumn{2}{|c|}{ Tax refunds } & $6 \%$ & $94 \%$ \\
\hline & \multicolumn{2}{|c|}{ Financial records } & $18 \%$ & $82 \%$ \\
\hline \multirow[t]{3}{*}{ Modernization } & \multicolumn{2}{|l|}{$\mathrm{ICT}$} & $83 \%$ & $17 \%$ \\
\hline & \multicolumn{2}{|l|}{ Reforms } & $59 \%$ & $41 \%$ \\
\hline & & & Properly used & Not properly used \\
\hline \multirow{2}{*}{\multicolumn{3}{|c|}{ Accountability of income tax revenue }} & $47 \%$ & $53 \%$ \\
\hline & & & Formal & Informal \\
\hline \multicolumn{3}{|c|}{ The structure of economy } & $2 \%$ & $98 \%$ \\
\hline
\end{tabular}




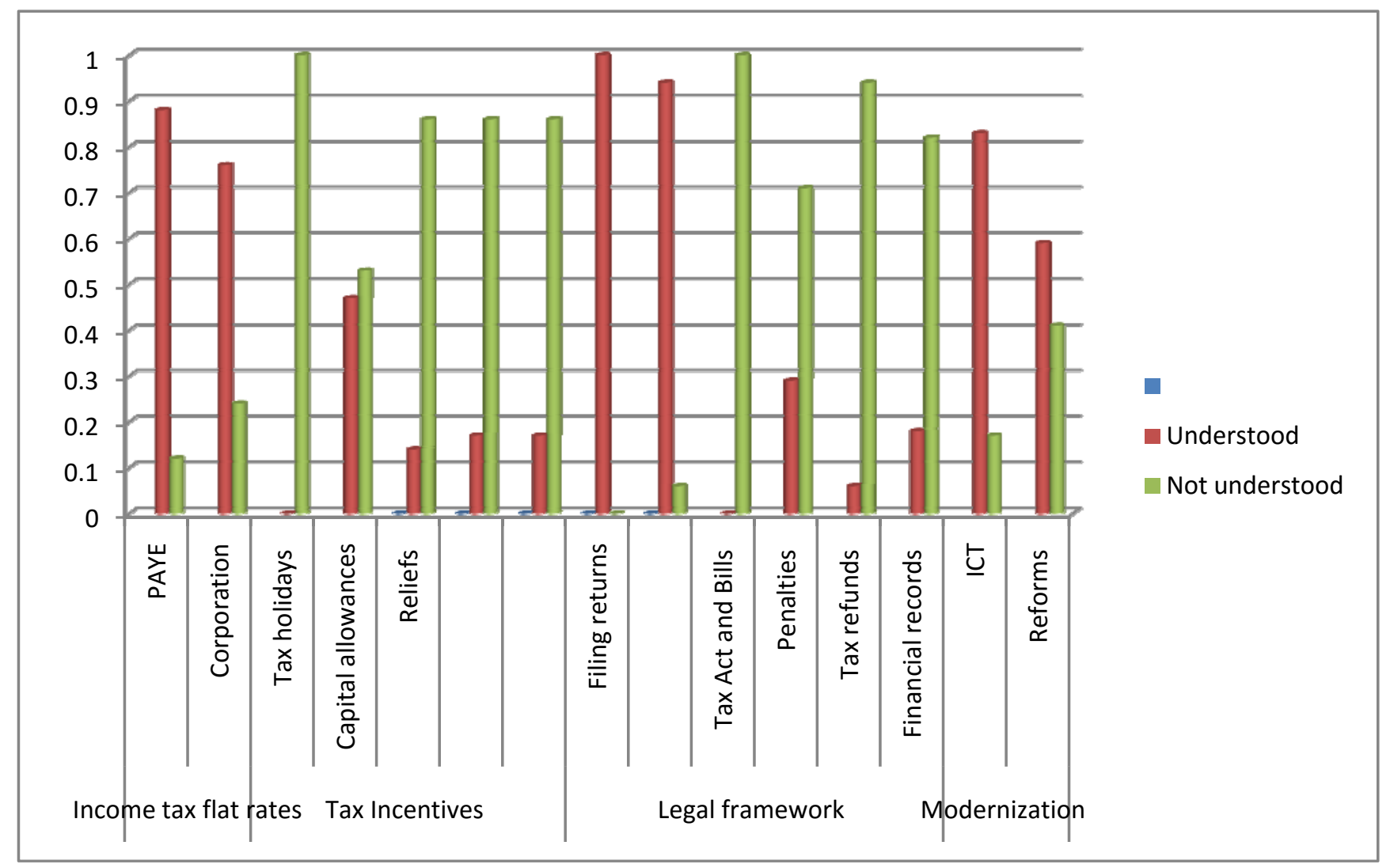

Figure 1. Results and Findings

The average of $82 \%$ of the respondents understood and applied income tax flat rates, and $18 \%$ did not.

The average of a mere $19 \%$ of the respondents knew about the tax incentives offered tax payers by KRA meant to motivate them to comply with income tax payment, and $81 \%$ did not know.

A hundred percent of the respondents filed PAYE returns and 94\% filed corporation tax returns. Eighty two percent of the respondents read the income tax Act but said they did not understand it as it was lengthy and complex. Twenty nine percent of the respondents understood the income tax penalties. A mere $6 \%$ of the respondents knew and applied for tax refunds; and only $18 \%$ knew how long financial records should be preserved for income tax purposes.

On average, $71 \%$ of the respondents were aware of efforts being made by KRA to improve the compliance on income tax; $83 \%$ used KRA ICT platform to make income tax transactions.

Forty seven percent of the respondents were satisfied with the utilization of income tax revenues by the Government. 


\section{Discussion}

The purpose of the study was to establish the factors which determine income tax compliance in Kenya. The primary data was collected from 237 companies operating within the Nairobi County using simple random sampling technique. Nairobi was selected for the sampling since it largest County in Kenya in economic performance. All the selected companies are from the manufacturing sector of the Kenya's economy. The analysis of the data and presentation of findings was made using the SPSS version 20.

Income tax is a direct tax charged on incomes of individuals and corporate entities. Individual income tax rates are based on employment income and benefits, self-employment, profits on trading activities, rent, dividends, interests, pensions, royalties, professional fees, and other incomes. Employment benefits include housing, car, per diem, commissions, international passage, medical cover, insurance premiums, loans, utilities, school fees for children, meals, pensions \& gratuities and benefits in kind. Some of these sources of income on individuals may not be accounted for via the PAYE system, with different rates applied on each. In addition, there are different income tax rates for residents and non-residents as well as directors.

Only $15 \%$ of the respondents were willing to disclose other benefits paid to employees other than salaries and wages, for tax purposes. Therefore we could not establish how various benefits including insurance premiums, mortgage payments, car benefits, per diems, housing allowances, and utilities were treated for income tax purposes. It is important to note that these benefits are taxed at different rates on a graduated scale. Eighteen percent of the respondents did not include salaries and wages in the PAYE payroll system, meaning that their employees were not taxed. Thirty percent of the respondents did not endeavor to find whether employees in their payrolls were working for other entities and/or earning taxable income from other sources, implying that it is difficult to bring all employee earnings in the tax bracket. However, most taxpayers appreciated that most benefits were taxable.

Thirty five percent of the respondents did not know their business's initial capital outlay, making it difficult to claim capital allowances. Twelve percent of the respondents had initial capital outlay ranging from Ksh 5 to 10 million, but only $47 \%$ of these claimed capital allowances. A hundred percent of those with turnover of less than Ksh 5 million, and are supposed to apply three percent tax rate, actually applied thirty percent, translating to a huge tax expense. A hundred percent of the respondents from the listed companies did not indicate the percentage of listed shares, and neither did they indicate the number of years they have been listed, and yet tax rates are a function of both.

The taxation authorities provide tax incentives aimed at improving on income tax compliance. These are tax holidays, capital allowances and reliefs. A tax holiday is a temporary period, during which time the government removes certain taxes on certain items, in order to encourage the consumption or purchase of these items. Capital allowance is a reduction in the amount of corporation tax payable, offered as an incentive for investment in large-scale projects. A certain percentage of the capital asset's cost is allowed as capital allowance during the accounting period in which it was purchased. This amount is greater than the depreciation 
charge on the asset during that period. A tax relief is any program or incentive that reduces the amount of tax owed by an individual or business entity. A hundred percent of the respondents did not apply for tax holidays, indicating that they were unaware about it. Forty seven percent of the respondents were unaware of the existence of the capital allowances. Fourteen percent, seventeen percent and seventeen percent of respondents did not apply pensions, insurance and mortgage reliefs for income tax purposes respectively. Eighty eight percent of the respondents engaged consultants and other professionals; eighty percent of these withheld tax on the payments. Eighty five percent applied National Social Security fund (NSSF) and National Hospital Insurance Fund (NHIF) tax reliefs correctly.

Income tax is governed under the Income Tax Act Cap 470, of the Laws of Kenya. The principle law of the Income Tax Act has 14 parts, 133 sections and 13 schedules, all directing its implementation. The Act is bulky, with heavy legal jargon undertones. Subsequent Finance Bills and Acts are issued on a continuous basis, with the aim of making amendments on the tax laws appearing in the Income Tax Act. The Finance Acts and Bills are written on a 'delete -insert' basis, further complicating the system, and making it more unfriendly. This brings to fore, a glaring complexity on the ordinary citizen and professionals alike. The results of our survey indicate that none of respondents understood the Acts and bills. A mere twenty nine percent, six percent, and eighteen percent of the respondents understood the income taxation penalties, refunds and preservation of financial records respectively. Seventy one percent of those aware of the applicable penalties described them as unfair. Penalties are charged by the tax authorities as deterrent to non-income tax compliance. Penalties are applied on instalment, final, withholding, PAYE, and the filing of self-assessment tax returns. Penalty rates range from five to twenty five percent on the unpaid amount, and a monthly compound interest charge of two percent. Tax refunds are payments made by KRA to the tax payer on account of overpayments of income tax. KRA has been weak in making the follow-ups on this important area to the tax payer. Individuals and corporate entities are required under the Act to preserve their financial records for a minimum period of seven years. A hundred and ninety four percent of the respondents filed their PAYE and corporation tax returns correctly, respectively; but none of them knew the date of filing the corporation tax returns, against $77 \%$ who knew the date of filing the PAYE returns. Five percent claimed that their corporation returns are filed by their external auditors. Seventy one percent did not know the amendments introduced in the new finance bill requiring that individual employees file their own personal income tax returns.

Modernization of the income tax system involves the transformation of the structural tax agency and the inculcation of ICT and is crucial for improved income tax compliance. Eighty three percent of the respondents were using the KRA ICT platforms, but indicated that the system is inaccessible most of the times. This explains why there are always long queues at the KRA offices. Furthermore, respondents complained that penalties are applied even when the system was to blame for their delays in making returns and payments. Fifty nine percent of the respondents were aware of efforts being made by the tax agency to improve on income tax compliance; however sixty three percent of them said they needed continuous tax education, with some twenty percent suggesting the restructuring of the agency. Visits by 


\section{Macrothink}

Asian Journal of Finance \& Accounting

ISSN 1946-052X

2018, Vol. 10, No. 1

KRA staff are important in the modernization efforts. Eighty two percent of respondents said they were never visited by KRA staff, and those visited suggested that the cycle should be reduced from the current five year one. All of those visited indicated that the KRA staffs are competent. Furthermore, $53 \%$ of the respondents indicated that the income tax revenues were not properly utilised and accounted for. This no doubt, discourages the income tax compliance. Accordingly, all the hypotheses is supported.

\section{Recommendations}

Based on the research findings, there is the need to simplify the income tax systems to improve income tax compliance by:

1) Rewriting the income tax laws in a friendly business language to make them understandable and clear to the common tax payer, as opposed to the current legal jargon,

2) Minimizing the number of applicable tax brackets and rates in similar tax categories in an effort to reduce the income tax schedules so as to simplify them,

3) Companies to employ professional tax officers. To achieve this goal, it is recommended that Kenya Accountants \& Secretaries National Examinations Board (KASNEB) should design a program to train specialized tax officers,

4) KRA to employ tax educators and supervisors to improve that ratio of officers to tax payers,

5) Improvement on the accountability of tax revenues by the taxation authorities,

6) Rolling modernization programs at the County level, and

7) KRA Publicizing tax laws publications.

\section{Conclusion}

The researchers conclude that there is the need to carry out more elaborate research in the area in Kenya and other African Nations.

\section{References}

Business Daily Newspaper. (2013). Africa Loses Billions in Tax Evasion. Business Daily, 9th September, Nairobi, Kenya.

Cheeseman, N. \& Robert, G. (2004). Increasing Tax Revenue in Sub-Saharan Africa, The case of Kenya. The Oxford Council on Good Governance. http://www.ocgg.org/fileadmin/Publications/EY006.pdf, Accessed on 15, April 2014.

Holtzman, Y. (2007). Challenges in achieving Transparency, Simplicity and administering of the USA Tax Code. Journal of Management Development, 26(5), 418-427. https://doi.org/10.1108/02621710710748257

Institute of Economic Affairs-Kenya (IEA-K). (2006). Taxation and Tax Modernization in Kenya: A Diagnosis of Performance and Options for Further Reform. 
(http://www.ieakenya.or.ke/publications/cat_view/1-publications/4-research-papers?start=20), 'Citizen Handbook on taxation, 2012' (http://www.ieakenya.or.ke/publications/cat_view/1-publications/5-books), accessed on 14, April 2014.

International Monetary Fund (IMF). (2001). Tax Policy for Developing Countries. Economic Issue No. 27. (http://www.imf.org/external/pubs/ft/issues/issues27/\#1), accessed on 14 April 2014.

Kenya National Bureau of Statistics (KNBS). (2013). Fact and Figures.http://www.knbs.or.ke/index.php?option=com_phocadownload\&view=category\&id= 20:kenya-facts-figures\&Itemid=595, accessed on 14 April 2014.

National Treasury. (2013). Kenya Monthly Debt Bulletin.http://www.treasury.go.ke/index.php/resource-center/cat_view/124-debt-reports/108monthly-debt-bulletin, accessed on 15, April 2014.

Office of the controller of budget. (2014). Budget Implementation Review. file://C:/Users/User/Downloads/Budget\%20Implementation\%20Review\%20fourth\%20Quat er.pdf, accessed on 23, May 2014.

Price Waterhouse Coopers (PWC). (2014). Doing Business: Know Your Taxes, East Africa $\operatorname{Tax}$ Guide

2013/2014.

http://www.pwc.com/ke/en/publications/east-africa-tax-guide-2013-2014.jhtml, accessed on 13, April 2014.

Tax Justice Network for Africa. (2014). Taxation and State Building in Kenya: Enhancing Revenue Capacity to Advance Human Welfare, Kenya Report.http://www.taxjusticeafrica.net/category/country-tax-reports, accessed on 13, April 2014.

World Bank. (2013). Kenya Economy Update, Edition No.8:Produced by Poverty Reduction and Economic Management Unit Africa Region,www.worldbank.org/kenya/keu, accessed on 13. April 2014. http://www.tradingeconomics.com/uganda/tax-revenue-percent-of-gdp-wb-data.html, accessed on June 29, 2014. 